\title{
Some Values of the First Folklore Work with Scientific Criteria ("Songs and Cries from the Scorched Town", of Mitrush Kuteli, Pogradec, 1944)
}

\author{
Teuta Kafexholli \\ Faculty of Philology, University of Prizren "Ukshin Hoti", \\ St. Rruga e Shkronjave, nr.1, 20000, Prizren , Kosovo
}

\begin{abstract}
Mitrush Kuteli's composition consists of many areas of activity. He is not only known as a prose writer with stories and novels, as a researcher (critic), translator, journalist and publicist, an activist for national cause with newspapers and magazines "Bota letrare" (the World of Literature), "Shqipëria e re" (New Albania) etc., as one of the founders of the Writers' League of Albania, as leader of the Albanian students in Romania, folklorist and poet, but also as a prominent economist. As a folklorist he published "Songs and cries from the scorched town", "Places of exodus in folk songs" (study), "Albanian folk proverbs" (Romanian), a collection of 140 folk songs, "Ancient Albanian Tales", "Xinxifilua" and other tales, a text on folklore for high schools of Tirana, etc.Our analytical target is Mitrush Kuteli's work "Songs and cries from the scorched town" published in 1944, is a collection of oral songs collected in the region of Pogradec. The songs of the book in question are equipped with appropriate biographical notes of the subjects from whom the songs were recorded. This work is considered as the first folklore work with scientific criteria. We need to emphasis that the work has been forgotten not because of the lack of values, but because of the communist political ideology in Albania. We will concentrate on the XIX circle of the work named cries, it is noteworthy that the term "cries" (brithma) was used for the first time to describe children's songs in Albanian folklore by Kuteli. The songs are on the last pages of the book (p. 127-148) with a total of 70 cries.

Keywords: Mmitrush Kuteli, folklore subjects, scientific criteria, cries, collectors, researchers, folklorists, subjects DOI: $10.7176 /$ JLLL/72-06
\end{abstract}

Publication date:October $31^{\text {st }} 2020$

\section{Introduction}

Folklore has been Mitrush Kuteli's permanent spiritual manna. When he was in exile he was spiritually nurtured by folklore. He collected folklore from Albanians in exile, a work he continued even when he returned to Albania.

His work "Songs and cries from the scorched town" is a product of his stay in Pogradec. He collected the songs and endowed them with proper notes. We are reemphasizing that with these notes, he is declared the first folklorist to publish a book with scientific criteria, the merit which has been denied to him by the Albanian science.

Based on reviewing and studying Kuteli's works, we learn that this writer, this economist, has attended a folklore course in Romania. This will be the reason why he had a scientific stand towards the subject of folklore. He has also written a text for high school students on folklore that he has unfortunately been lost.

Ten years before publishing "Songs and cries from the scorched town", Mitrush Kuteli studied the expansion of the Albanian song in the work titled "Places of exodus in Albanian folk songs."

In this study published more than 80 years ago, Kuteli has articulated his opinions and drew conclusions of scientific interest. He is an excellent connoisseur not only of Albanian poetry but also of Balkan poetry. He brings us examples that prove the geographical extent of the Albanian folk song, asserting that the empire of our song is immensely wide "it extends from Spain to Brusa and maybe even further, from the Crimea to Abyssinia". ${ }^{1}$ Thus, it is proved that the Albanian song conquers with its toponymy the three continents with the earliest of songs, and with the later ones the other two continents, namely America and Australia.

This work "Places of exodus in Albanian folk songs." should be considered the first in the history of Albanian folklore that expresses a distinct preoccupation, on which a specific work can be done.

\section{About the work "Songs and cries from the scorched town"}

The work "Songs and cries from the scorched city" published in 1944 is considered the one that directly and in particular lists Kuteli as a collector, publisher and researcher of folk poetry.

In this rare collection we also find Kuteli as a folklorist who sang the song himself (sometimes as a personal remembrance); but in this folklorist we find it both sung and written, both classified and published and studied conscious that the time which has created this treasure is also ruthless enough to obliterate it.

By publishing this work, M. Kuteli will show full awareness of what E. Çabej says ever since Kuteli was at the peak of economic and poetic studies. Here is the opinion of E. Çabej: "A regional geographical division of

\footnotetext{
${ }^{1}$ Mitrush Kuteli, “Literary Work 5”, Prepared by Nasho Jorgaqi, Naim Frashëri, Tirana, 1990, p.176.
} 
Albanian folk songs cannot be undertaken either from their spiritual content, from the meaning of the world, neither from their formal side, nor from the internal means of expression such as metaphors and figures. Because these elements are represented here, in the same manner everywhere, so their study gives a much stronger conclusion to their condensed unity than the division of Albanian folk song. A division can be made more easily after the external means of expression, from metrical-rhythmical and musical aspect: after the verse and the melody. "However, the long-term influences have been so uninterrupted in this area that we can now talk about significant local changes".

There were attitudes of total ignorance but also high appraisals for the work "Songs and cries from the scorched town". So, the work has been forgotten not because of the lack of values, but because of the communist political ideology in Albania.

I am highlighting some of these thoughts. Kuteli himself in "Kujtesa" had literally said it like this: "In 1944 I published the collection "Songs and cries from the scorched town", which is one of the first collections with scientific criteria...". 2

Whereas Kuteli says "one of the first collections with scientific criteria", a scholar such as Aurel Plasari in his book "Kuteli between the living and the dead" on p. 32 says: "... In the collection 'Songs and cries from the scorched town' it's subject maybe does not bring something new, however in Albanian folklore the novelty was the way of dealing with this subject: biography and short portrait of the subjects to have given him the songs, notes for the history of these songs etc. It can be named the first folklore collection with such criteria published in Albania. As he himself explained, he had learned this method in a course organized by the Romanian Institute of Sociology for collectors of folklore. ${ }^{3}$

In one case, Kuteli himself says: "My stories are a reflection of the stories of the elders and not a reflection of any written literature. At the end of some stories I have also put the name of the one who had told me the story. Why? For gratefulness. Man, therefore the writer, must be honest with the one who has helped him. I had done the same in the fairy tales of the volume "Xinxifilua", but the editorial office found it appropriate to draw a black line on them, to erase the names. And I'm sorry". ${ }^{4}$

\subsection{The semantics of the notion of cries in Kuteli's work}

Let us approach the work in question and the complete works of M. Kuteli on the issue of his vocabulary. In "Songs and cries from the scorched town" we highlight that children's songs are called cries. Not in any other work of this nature has this term been used, although Kuteli has clearly differentiated, also in other times, the semantics or meaning of the cry (brithma), which is sometimes written in TH and sometimes in T. In terms of word formation, the phenomenon of a diminutive suffix - TH is clearly noticed. We first encounter this in Frank Bardhi's "Latin-Albanian Dictionary" (1635) (the first lexicographical work of our language. For example, the word zokth - "avicula"). The suffix TH is often used to give the word an emotionally caressing nuance. These suffixes are characteristic of the Italian-Albanian communities, which are mostly of Tosk origin and which have preserved an archaic shape of the Albanian language.

In this respect Mitrush Kuteli remains sui generis for a folklore genre - the children one. It remains unique, because ever since the first folklore work, then also since the publication of the most capital work of Albanian folklore "Bleta shqiptare" 5 , in no other work has this term been used.

We underline again that Mitrush Kuteli with CRIES means a kind of spoken creation. This type is: children's songs, lyrics or games vowel rythem. Such songs, cries, are listed in the last pages of the book and numbered (127143), in total: 13 of the first group; 13 of the second group; 18 of the third group; 13 of the fourth group and 4 of the fifth group, meaning a total of 61 cries.

Let us stay a little more with this term. Many readers or scholars, as soon as they come across the book "Songs and cries from the scorched town" understand the second word of this book but also misunderstand it, not as used and explained by M. Kuteli but in a different manner.

The same author, apart from "Songs and cries from the scorched town" has used the same word in Noli, the poet, where cries means -the scream- and not a term for a folklore or literary genre. In this respect it has remained, unique or special.

Here is how Kuteli expresses exactly about the notion of cries and the selection made within the title of the work: As for the title of the collection, "Songs and cries from the scorched town", I chose this for the meaning of the tragic moments my eastern ${ }^{6}$ state has gone and is going through from December 1940 onwards. For this reason,

\footnotetext{
${ }^{1}$ E.Çabej "On the genesis of the Albanian literature", Prishtina, 1970, p.55

${ }^{2}$ Kujtesa e perkthenjesit, f.222 tek S. Bashota.

${ }^{3}$ Kujtesa...and "Hylli i Dritës"” 3-4/1944, f.62. Quoted after A.Plasarit, Kuteli between the living and the dead, Apoloni,Tirana, 1995 , p.32.

${ }^{4}$ Ibidem, f. 38

${ }^{5}$ Thimi Mitko, "The Albanian Bee", published in Alexandria, Egypt, 1878

${ }^{6}$ Eastern (motherland)
} 
entirely, the summary begins with the songs of lament. ${ }^{1}$ This conclusion about the title of the book is clearly related to what he said about Noli as above. The same author in the part of the book "Who gave me the songs", says: "Rini (Irini) my 5 years old niece, voiced me some cries of the age (underline T.V.K), some song distich heard by the elders and the little ones of the neighbourhood". ${ }^{2}$

Therefore, the word cries is rare and isolated only in the folklore region of Pogradec. It enters the group of rare words as passivized lexicon. M. Kuteli is particularly distinguished for the use of rare words left in the oblivion of time.

When you take in your hands the book "Songs and cries from the scorched town", the author's publication, Tirana.1944, you are convinced that this work not only has folklore subjects of interest and untouched by scholars, but the two prefaces also arouse scientific interest.

The author's first preface is entitled "Songs are brought by the wind" (which covers four pages) and "Who gave me the songs" (six pages in total).

2.1.1. The division of the work into cycles

The songs in this book are arranged in these cycles: I Songs of lament (with 7 songs); II Songs of old age (with 4 songs); III Songs of war and bravery (with 16 songs); IV Love songs (with 18 songs); V Wedding songs (withrituals; 27 songs); the ones for jollity (30 songs); for jollity and mockery (10 songs), so with 67 wedding songs in total divided in three groups; VI Easter songs (with 9 songs); VII Songs for flowers and shabby girls (with 8 songs); VIII Various songs (with 8 songs); XIX Cries (with 51 songs), up to page 145. This cycle continues also with the Mockery cries for different names (with 13 songs); Further two subdivisions of this cycle follow, titled Other cries of mockery, and For the ones that don't fast (with only 4 songs).

Let us go back to the notion of cries that Kuteli classifies in his work in the XIX cycle, that is, for children's songs. In no other work of this nature has this term been used, although Kuteli himself has differentiated the meaning of this word from this term. I do not know of any other folklore region that it has been used as in "Songs and cries from the scorched town", so both the cycle and the songs and the term is a poradecian sui generis.

Reading the cries from the work in question, you feel as if you are imaginatively going back to the world of childhood and sentiment with texts, games like that "Tu-tu-tu legëza"/Vajta për purtekëza" with its full variants and full of figures of paradoxes (p.128) one with 19 verses and the other with 18, which Kuteli marks as a personal memory ("I said it as a child").

Cries, which Kuteli himself has learned since he was a child and noted them in "Songs and cries from the scorched town", are plenty. One of them is "Këndon bufi në Goric/ Zymbyle moj, Zymbylicë/ Çon e fton gjithë miqësinë/ Kukumjaçkën e harrojti.../ Kukumjaçka u zembërua,/ Pse s'më ftoj ky bufi mua,/ T'i vinja me një peshqesh/ Me një mace me lesh..." and gives the note" It is said that the owl likes eating cats ". (F.131). A group of cries are motivated by lost things, hidden things, small things that are put in the friend's shoulder to play or when the magpie comes near the house, for which it is believed that a letter will come from afar, etc. etc. and Kuteli explains how a lost item should be found or how it is developed and sung in such cases. (F.133).

Other cries follow for the winter, snow, pancakes, bear, Christmas (with the explanation that "Igënashti thonë pleqtë, hidhet këndezi nga grazhdi se merr dita nga nata). From the new cries of childhood that are numbered from 1 to 18 are distinguished those that are connected with his time period and his ironization of it: "Rroftë Duçja, /Rroftë mbreti/Që na sjell/Sheqer nga deti;/Me kuintal'/ E ha mbreti/ Me drehem/ E ha mileti/ (p.144). Another of cries emphasizes the dialogue between the friend or, as Kuteli says, the pal: "Mikja ka çu letër/ Du me u pajtu-/ Po në gjeça shoqe/ miken nuk e du./ Daç u marto, daç mos u marto/ Daç shko në kishë/ Bëju kallugre./ From new cries as Kuteli himself gruops them, it singles out: "Kam një kumbull/ Në shtëpi/ Do ma haj/ Harap i zi,/ Do ma haj/ Pra nuk e di/ Do-re mi- fa sol-la-si./ (p.142). A group of cries are said about persons known in the respective environment as: "Hani pini e këndoni/ Sa të rrojë Papandoni,/- Po të vdesë Papandoni:/ Merrni torbat e kërkoni!/, noting that Papandoni is Andon Velo teh priest in Pogradec. Cries of mockery for names or known or unknown persons has a verse. Here is one of them: “Tushi, Kobure pe bushi,/ Shkrap e shkrup!/ Asnjë s'të ndezi/ Lyeje me glasë këndezi/. Thus, Kuteli recalls or collects, marks many cries for all domains of children's lives and from the children.

It is acknowledged that M. Kuteli reaches the culmination value in his stories. One of the qualities of his prose is the inclusion or entanglement of cries or yearly songs in the context of Kutelian prose. The aspect of the inclusion of folklore in the characters of Kuteli's stories is a special topic that also deserves a special monographic study.

With intent to give the portrait of the girl, the bride, the groom and other characters of "Songs and cries from the scorched town" we shall mention that their portrait in Kuteli appears, also, in love songs, wedding songs, but also in humorous ones etc. with differentiated nuances in humorous lyrics and in those artistic pearls that amaze with their perfect poetics.

Thus with the girl (woman), he describes the physical beauties and those of the soul, that is, the spiritual

\footnotetext{
${ }^{1}$ Mitrush Kuteli, "Këngë e britma nga qyteti i djegur”, Tiranë, 1944, f.10.

2 Ibidem, p.15. Also, in "Ago Jakupi and other tales" of 1943 in p. 136 the word cries is used.
} 
beauties. Here are the features that predominate in the description of the poradecar girl: hair, forehead, eyebrows, eyes, mouth, cheeks, teeth, lips, ears, breasts, hands, body, legs, nose and many other physical and almost as much spiritual features. All these features take epithets, metaphors, comparisons and other tropes that really make the poetics of the song come alive according to the respective contexts.

These features will be: dark eyes, eyebrows, blond, dark eyebrows, eyebrow-perch, red turban, dotted, curvyeyebrow, white-gills, waist-thin, lip-bud, red-cheek, etc. etc.

And so, looking at, analyzing, generalizing, clarifying, the researcher makes an external and internal approach to the life of the song and its poetics, thus touching on elements of study work for a lyric that has kept alive the artistic life of the people for centuries. This way, with spiritual nourishment, he has kept alive the life of the people in the Scorched City, the city by the lake of Mitrush

\section{References}

KUTELI, Mitrush, Pylli i gështenjave, NSHBT, Tiranë, 1958.

KUTELI, Mitrush, Sulm e lot, Tiranë, 1944.

KUTELI, Mitrush, Testamenti, Drita, 8.V.2006.

KUTELI, Mitrush, Tregime të moçme shqiptare, Rilindja, Prishtinë, 1971.

MHSH, I.F.Tiranë, 1961 (tri vëllimet).

PAPLEKA, Ndoc, Kulte, rite, magji në traditën orale,Toena, Tiranë 1999.

PASKO, Atalanta, Prozë dhe vargje të zgjedhura,SHB M.Kuteli, Tiranë, 2001.

PLASARI, Aurel, Kuteli midis të gjallëve dhe të vdekurve, Tiranë, Apolonia, 1995.

ZHEJI, Gjergj, Folklor shqiptar, Tiranë, 1998. 